\title{
E-HRM practices and sustainable competitive advantage from HR practitioner's perspective: A mediated moderation analysis
}

\author{
Mohamed Dawood Shamout ${ }^{a}$, Malek B. Elayan ${ }^{b}$, Adnan M. Rawashdeh ${ }^{c}$, Barween Al Kurdid, \\ and Muhammad Alshurideh ${ }^{\mathrm{e}, \text { * }^{*}}$
}

${ }^{a}$ Department of Management, College of Business Administration, University of Sharjah, Sharjah, United Arab Emirates

${ }^{b}$ Business Administration Department, Institute of Public Administration, Riyadh, Saudi Arabia

${ }^{c}$ The University of Jordan, Jordan

${ }^{d}$ Department of Business Administration, Faculty of Economics and Administrative Sciences, The Hashemite University, Zarqa, Jordan

${ }^{e}$ Department of Marketing, School of Business, The University of Jordan, Amman, Jordan

${ }^{f}$ Department of Management, College of Business Administration, University of Sharjah, Sharjah, United Arab Emirates

\section{H R O N I C L E}

Article history:

Received: June 18, 2021

Received in revised format: June

29, 2021

Accepted: September 19, 2021

Available online: September 19, 2021

Keywords:

E-HRM Practices

Sustainable Competitive Ad-

vantage

TAM-PAM Constructs

Mediated-Moderation Model

\section{A B S T R A C T}

This paper seeks to investigate the impact of Electronic Human Resource Management (e-HRM) practices on attaining Sustainable Competitive Advantage (SCA) in the context of the Jordanian Industrial Sector (JIS) and identify the mediating role of e-HRM Perceived Usefulness (PU) and eHRM Perceived Ease of Use (PEOU). Furthermore, it investigates the moderating role of User Satisfaction and e-HRM Continuance Usage Intention. To achieve the paper objectives, a MediatedModeration Model was designed. The researchers distributed (750) questionnaires, (615) questionnaires were returned and validated for analysis in HRM and development divisions and based on a Census method with the response rate was about (82\%). The 'Structural Equation Modeling' (SEM) methodology was used, and for analysis, SPSS and Amos were applied. The results indicated that eHRM practices had significant influence on SCA. The paper also demonstrated that there was a significant mediate effect of TAM constructs on the relationship between e-HRM practices and SCA. Finally, the findings indicated that the user satisfaction and e-HRM continuance usage intention did not moderate the relationship between e- HRM -PEOU and PU and SCA path.

\section{Introduction}

Nowadays, the most successful organization leaders realize the power offered by Information Technology (IT) tools for achieving business sought-after ends (Ghazzawi, Al-Khoury \& Saman, 2014). Due to the intensive competition between organizations in order to attract and retain the existing professional employees, organizations are becoming more efficient by using "Electronic Human Resource Development" (E-HRM)(Ammari et al., 2017; Al Kurdi et al., 2020; Kurdi et al., 2021; Alaali et al., 2021). E-HRM has become an important strategy to support strategic decisions and achieve a Sustainable Competitive Advantage (SCA) for developed organizations (Stone, Stone-Romero \& Lukaszewski, 2006; Alameeri et al., 2020; Alsuwaidi et al., 2020). E-HRM can help organizations to enhance their function pertaining to HR activities, bringing benefits of cost savings, efficiency, flexible services, and employee's participation. Organizations are recognizing the importance of e-HRM in terms of competition, selecting and retaining the outstanding employees and maintaining the company's reputation (Ruel, Bondarouk and Looise, 2004; Strohmeier, 2007; Alsuwaidi et al., 2020). The Jordanian Industrial Sector (JIS) strives to cope with new changes and adopt SCA to survive in the global economy. The main concern of this study is where Jordan stands with respect to the implementation of IT applications, especially in the field of HR, and it is

* Corresponding author.

E-mail address: malshurideh@sharjah.ac.ae (M. Alshurideh)

(C) 2022 by the authors; licensee Growing Science, Canada. doi: $10.5267 /$ j.ijdns.2021.9.011 
also concerned with determining and evaluating the impact of e-HRM on JIS. Even though JIS plays a vital role in the Jordanian economy, it faces aggressive competition in the domestic and global market. Hence, JIS sector is implementing eHRM in order to ensure a participative HR department administratively and strategically, to achieve its goals precisely and sufficiently in order to tap into the global talent pools as a competitive tool (Alajmi \& Alenezi, 2016; Al Kurdi et al., 2021; Al Shebli et al., 2021). Accordingly, the main aim of this paper is to investigate the impact of e-HRM practices on attaining SCA from HR perspective and identify the mediating role of Technology Acceptance Model (TAM) constructs: e-HRM Perceived Usefulness (PU) and Perceived Ease of Use (PEOU) between e-HRM practices and attaining SCA. Furthermore, it investigates the moderating role of Post-Acceptance Model (PAM) constructs: User satisfaction and continuance usage intention towards e-HRM, more specifically, the researchers assess a three-way interaction between (1) User satisfaction and continuance usage intention and e-HRM-PEOU (2) User satisfaction, e-HRM continuance usage intention and e-HRM-PU.

\section{Research Contribution}

The contribution of this paper emerges from the fact that it provides a comprehensive picture of the relationship between eHRM practices and SCA, alongside mediators and moderators. Moreover, the data used for this paper originates from an HR perspective through various industries in Jordan. This implies that the data is not unique to a single firm, sector, or industry, but instead, representative of major HR professionals in Jordan. The research's magnitude is acquired from the value of eHRM which represents the ultimate investment of IT with the HR department at JIS, which is considered as a new strategic technological and organizational tool to achieve SCA. An integrated conceptual framework developed to investigate a Mediated-Moderation model the impact of e-HRM practices (e-Recruitment and e-Selection, e-Compensation, e-Training and Development, and e-Performance Management) and attains SCA (Operational, Relational, and Strategic Effectiveness). This framework integrates ideas and elements from the Technology Acceptance-Post-Acceptance Models and the adoption studies in the area of e-HRM and examines the mediating role of e-HRM-PEOU and PU. Furthermore, it investigates the moderating role of User Satisfaction towards e-HRM and Continuance Usage Intention between (e-HRM-PEOU and PU) and SCA.

Jordan has a sizable and profitable JIS, and most companies try to attract a wide range of professional HR, therefore investigating e-HRM practices is essential to attain SCA to develop and enhance JIS performance. Moreover, the researchers choose JIS as a research area, because it is one of the largest sectors listed in the Amman Stock Exchange Market (ASEM) and a great deal of data about the JIS is available from the ASEM. Furthermore, they suppose that e-HRM will enhance its performance and attain SCA from HR perspective. Therefore, this paper was conducted with confidence and reliability, as it meets the expected scale of study and presents useful study material, in addition to the high reliability during conducting the study on a realistic basis as it has chosen e-HRM practices in JIS because the perfect opportunity to complete the requirements of this paper and explore the impact of e-HRM practices on attaining SCA in one of the most important sectors in Jordan was found. The findings arrived at in this paper will benefit not only academics, but also HR managers within the context of JIS and any other sector. Furthermore, the paper could support HR managers; it enables them to construct HR departments, which are considered to have strategic significance to any modern business. Additionally, it steers academics in the direction of appreciating the background of e-HRM within the context.

\section{Literature Review and Hypothesis Development}

\subsection{E-HRM Practices and SCA}

Several previous studies have shown that e-HRM is a significant predictor of attaining SCA and leads to an increase of HRM effectiveness (Bondarouk et al .2017; Bondarouk and Ruel, 2009; Sanayei and Mirzaei, 2008; Ruel Bondarouk, \& Van der Velde, 2007; Bell, Lee, \& Yeung, 2006; Elayan 2020). According to Legnick-Hall and Montiz (2003), e-HRM has the potential to affect both efficiency and effectiveness. Efficiency can be affected by reducing cycle time for processing paperwork, increasing data accuracy, and reducing HR staff. Effectiveness can be affected by improving the capabilities of both managers and employees to make better, timelier decisions. Hendrickson (2003) revealed that e-HRM supports organizations to attain SCA through increasing productivity and providing strategic capability. Marler and Fisher (2010) indicated that automating HR practices is transforming the traditional paper-and-pencil, labor-intensive HR tasks, into efficient, fast-response activities that enable companies to create a much-needed SCA.

Panayotopoulou et al. (2007) emphasized that e-HRM facilitates the transformation of HRM role into a strategic one and Ruel, et al. (2007) noted that e-HRM application affects HRM technical and strategic effectiveness and found that using eHRM will reduce costs, enhance the HR service level, and supply the HR department space to become a strategic partner. Furthermore, Haines and Lafleur (2008) found that greater use of IT was linked with HR effectiveness and greater involvement in the strategic roles of business partners. This notion also received empirical support from Ruel and Kaap (2012), who added that e-HRM can enhance HRM value creation. Value creation has to do with the creation of efficiency and HR service quality in an organization, as e-HRM may help HR to increase its value (Rangarao \& Raju, 2014; Wahyudi \& Park, 2014; Parry \& Tyson, 2011; Rawash \& Saydam, 2012). Oswal and Narayanappa (2014) argued that e-HRM could enhance organizational effectiveness through developing HR policies. Thus, e-HRM can help the organizations to upgrade the HR policies for web-based technology to support both efficiency and effectiveness of HRM (Alkalha et al., 2012; Karampour, Nazari, Alinia, \& Kameli 2014). In another study conducted by Iyiola and Osibanjo (2014), which revealed that there is a strong positive association, exists amongst e-HRM practices and organizational performance. 
Deshwal (2015) measured the effectiveness of e-HRM for sustainable development of the organization and indicated that eHRM helps the organization to improve employee competences. Masum, Kabir and Chowdhury (2015) found IT infrastructure and industry pressure had influence the adoption decision for e-HRM. Findikli and Bayarcelik (2015) showed that use e-HRM directs organizations to reduce organizational costs, and effective communication between manager and employees. Khashman and Al-Ryalat (2015) indicated that e-HRM practices have positive impact on operational performance in the Jordanian telecommunications companies. Bondarouk, et al. (2017) concluded that e-HRM consequences transfer from operational effects to relational and then transformational (strategically) outcomes. Contemporary e-HRM technologies contain powerful functionality that can support organizations in attaining SCA in reducing the cost and improving the quality of HR service delivery, as well as enabling higher productivity and providing strategic capability. Despite the fact that several researchers have studied e-HRM, most of them were interested mainly with the impact of e-HRM on organizational effectiveness . There is, however, a lack of studies that attempt to examine the impact of e-HRM on SCA from HR perspective, specifically from three dimensions: HRM operational, Relational and Strategic Effectiveness. Therefore, the first hypothesis can be formulated as follows:

\section{$\mathbf{H}_{1}$ : E-HRM practices positively influence SCA.}

\subsection{The Mediating Role of TAM Constructs}

Many studies focusing on e-HRM indicated that there exists a positive relationship between PU and PEOU (Yarbrough \& Smith, 2007; Lee, Kim, Rhee, \& Trimi, 2006). As expected, e-HRM practices influence e-HRM- PEOU, in line with Voermans and Veldhoven's (2007) study, which identified PEOU as a determinant of intention of using e-HRM practices. This work predicted that e-HRM practices will influence e-HRM-PU, it conforms to prior findings of Marler and Fisher (2010), which illustrated that PU of e-HRM is an important contextual variable for e-HRM; and corroborated by Wickramasinghe (2010), who asserted that PU is associated with e-HRM systems signals some form of compatibility. From an HR manager's point of view, Laumer and Weitzel (2010) found that the most pressing challenges of an organization are staff retention and internal and external employer branding. They concluded that the importance of an e-HRM rests in providing effectiveness, i.e. adequately fill vacancies and efficiency, i.e. make full use of rare resources to achieve sustainable CA. The study hypothesized that e-HRM practices influence e-HRM-PEOU. Jaradat and Azaam (2013) indicated that there is positive correlation with statistical significance among sample individual attitudes towards the impact of HRM practices on achieving SCA, while Ghazzawi, et al. (2014) suggested a strong influence of PEOU of e-HRM on the employee's attitudes of using e-HRM and it is the main predictor of the attitude towards implementing e-HRM. E-HRM majorly relies on TAM model (Huang, Yang, Jin \& Chiu 2004). A study found that e-HRM has a connection with facilitating conditions, PEOU (Ruel \& Kaap, 2012). Yusoff, Ramayah, \& Othman (2015) indicated that PEOU and PU have a significant effect on attitudes towards using e-HRM. Contrary to Yousafzai, Foxall, and Gordon, (2012) who found that PEOU has less of an impact on technology acceptance than PU (Yousafzai, et al. 2012). This study has laid out the fact that e-HRM practices can enhance e-HRM-PU from HR perspective. Therefore, the study develops the following hypotheses:

\section{$\mathbf{H}_{2}$ : E-HRM practices positively influence e-HRM-PU. \\ $\mathbf{H}_{3}$ : E-HRM practices positively influence e-HRM-PEOU.}

Although some previous studies indicated that e-HRM-PEOU did not enhance strategic and technical HRM effectiveness (Ruel et al, 2007; Alshraideh et al., 2017). Kossek, Young, Gash, and Nichol, (1994) noted that "top managers showed high resistance as they did not perceive e-HRM systems having use for their own careers". Contrary to the above argument, Panayotopoulou et al. (2007), and Bondarouk, et al. (2017) provided earlier evidence by showing that e-HRM promised to lead to efficiency gains, and most researchers in the past decade advocated e-HRM's strong contribution to the bottom line. Huselid (1995) noted that technical and strategic effectiveness of HRM are activities governed in "socially constructed environments. Henceforth, meeting the expectations of stakeholders may equate to acceptance and organizational growth. This means that e-HRM-PEOU may increase organizational SCA. Hussain Wallace, and Cornelius (2007), verified the positive attitudes of HR professionals who perceived e-HRM as a crucial and enabling technology. Technically, due to recent global fierce competition, and organizational reengineering, this work attempts to observe how e-HRM-PU and SCA interact from HR perspectives. The current study attempts to examine impact of the e-HRM-PU and e-HRM-PEOU on SCA by developing the following hypotheses:

\section{H4: E-HRM-PU positively influences SCA.}

Hs: E-HRM-PEOU positively influences SCA.

According to Parry, \& Tyson (2011) indicated that e-HRM practices reduce time and effort needed for administrative tasks, increase accuracy of data and speed and ease of information sharing, and technically simplify all HRM processes. In doing so, e-HRM practices harmonize HR activities (Martin \& Reddington, 2010), asserting that better e-HRM- PEOU and eHRM-PUs are key determinants for the facilitation of focus strategy, value-adding tasks, and plans (Panos, \& Bellou, 2016). Hence, firms can easily gain SCA because of e-HRM practices well represented between e-HRM- PEOU and e-HRM-PU. E-HRM PU and PEOU raises the user's ability to understand processes easily, leading to better effectiveness, and thus re- 
sulting in cutting more costs that were previously spent on irrelevant tasks which no longer exist (Thiruselvi, Yusliza, Ramayah, \& Zahiyah 2013). Moreover, Bondarouk and Brewster (2016), it is user's perceptions of e-HRM applications that determine, to a great extent, how and whether e-HRM will be used. It is critical to note that e-HRM is a part of that wider picture requiring crucial analysis from PEOU and PU. Thus, this paper proposed the next hypothesis:

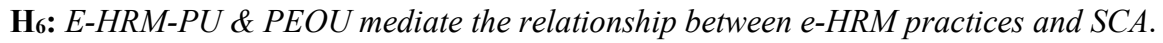

\subsection{The Moderating Role of PAM Constructs}

Many studies indicated that PU is positively associated with user satisfaction and emphasized the positive relationship between PU and satisfaction toward continuance usage intention (Anjum, 2011; Ho, 2010; Liao, Chen \& Yen 2007; Liao, Palvia, \& Chen, 2009; Naidoo \& Leonard, 2007; Yen \& Tsai, 2011; Al-Maghrabi, Dennis, \& Vaux Halliday, 2011). According to Bhattacherjee (2001), IS continuance intention is determined primarily by user satisfaction with prior IS use. Zeithaml, Berry and Parasuraman (1996) emphasized that high satisfaction often results in favorable behavioral intentions. Seddon (1997) indicated that user satisfaction is evaluation of the various uses and experiences of an IS which is based on continuance usage. Furthermore, Mahmood, Burn, Gemoets, and Jacquez (2000) validated that satisfaction with IT is viewed as a vital driver of its success. A study conducted by Bokhari (2005) revealed a positive relationship between IS usage and user satisfaction. In addition Bjorkman and Lervik (2007) added that satisfaction levels with existing HR systems in the subsidiaries are likely to have an influence on the adoption levels of new HR practices. E-HRM was reported as beneficial to employee satisfaction (Panayotopoulou et al., 2007) and satisfaction related to HR processes (Cronin, Morath, Curtin, \& Heil, 2006). In a related study, Ramezan (2009) indicated a significant relationship between system quality and information quality with user satisfaction. Martin and Reddington (2010) noted that user acceptance of IT applications can act as a "moderator" in the relationship between HR strategy and e-HRM outcomes

Measurement of user satisfaction has appeared in many IS research by authors (Ibrahim \& Yusoff's, 2013; Bhattacherjee, 2001; McGill \& Klobas, 2008; Schaupp, 2010; Wixom \& Todd, 2005). Moreover, Thiruselvi et al. (2013) found that there are significant relationships between TAM and PAM constructs, which are the PU and satisfaction were positively related to continuance usage of e-HRM, PU and confirmation were also found to be positively related to satisfaction, PEOU was found to be positively related to PU. Although many studies have been conducted on user satisfaction and continuance usage intention, very few studies have found user satisfaction and continuance usage intention as a moderate in the relationship between PEOU and PU, particularly to the users of e-HRM and its role in attaining SCA. Therefore, the researchers predict that the relationship between the PEOU and PU of e-HRM, plus user satisfaction and usage continuance toward e-HRM may provide better service that satisfies user expectations resulting to keep using it in alignment with organization vision towards sustainability and ability to have SCA. Accordingly, the researchers gauged for a potential three interactions of user satisfaction and e-HRM continuance usage intention which is adopted by PAM as a moderator variable on (1) the relationship between e-HRM-PEOU and SCA, and (2) the relationship between e-HRM -PU and SCA. Thus, this paper develops the following hypotheses (7-8):

$\mathbf{H}_{7}$ : User Satisfaction with e-HRM and Continuance Usage Intention moderate the relationship between e-HRM-PEOU and $S C A$.

H8: User Satisfaction with e-HRM and Continuance Usage Intention moderate the relationship between e-HRM-PU and $S C A$.

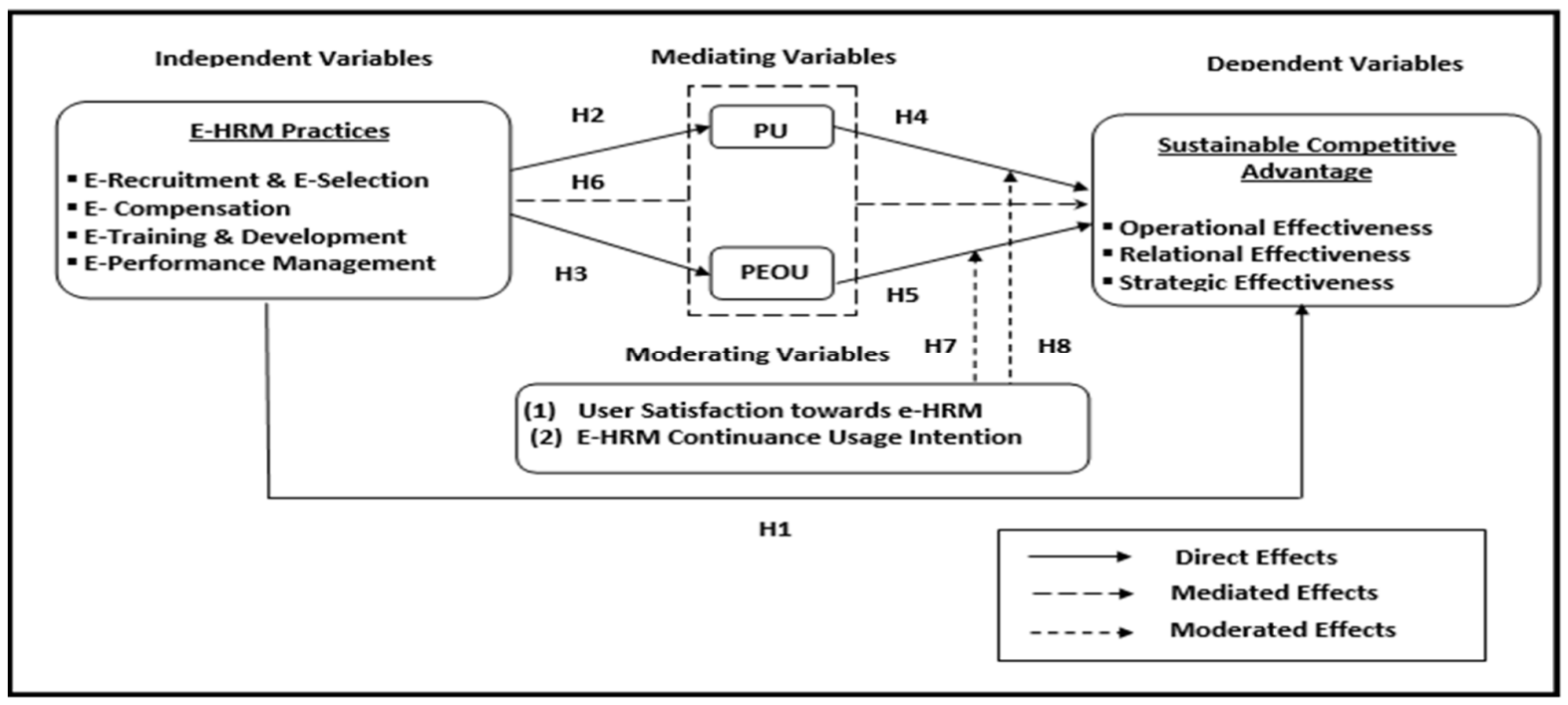

Fig. 1. The Proposed Model of the Research 


\section{Research Methodology}

\subsection{Design, procedure and Methods}

In this paper, a quantitative method is employed to test hypothetical deductive generalizations (Cavana, Delahaye $\&$ Sekaran, 2001). Hence, this chosen methodology was regarded as appropriate to the task at hand since, which is to explore causal relationships among the e-HRM practices, PU, PEOU, User Satisfaction, Continuance Usage Intention and SCA constructs (Zikmund, 2003). Data collected with the use of a self-administered structured questionnaire designed for fits the objectives of the paper and captures its variables, it is consistent with Saunders, Lewis and Adrian (2003) who strongly recommended the use of questionnaires for descriptive or explanatory objectives. In the current paper, the total number of (750) respondents in (63) companies in JIS collected from ASEM database, were considered from HRM and development divisions (Managers, Heads of Departments, and employees). The researchers targeted the total population based on Census method since it is considered the best way of getting accurate, valid and reliable information within the context of HRM. The researchers distributed (750) questionnaires were then directly distributed to them by hand and email, (615) questionnaires which were brought back and validly viable for analysis with all the questions having been offered to the Jordan's JIS entire HRM department where at the end the response was identified as being $82 \%$. Either the overall response rate or active response rate, however, it is 'high' and 'adequate' to carry out the data analysis, as pointed out appropriately by Saunders, et al. (2003: p.284). In the data analysis through the use of the SPSS and AMOS version of 201.0 software.

\subsection{Questionnaire Items and Measures}

According to measures, all e-HRM practices (e-Recruitment and e-Selection, e-Compensation, e-Training and Development, and e-Performance Management) was operationalized with a 19-items scale were developed by interviewing HRM experts within the context based on (Ruel \& Kaap, 2012; Bondarouk \& Ruel, 2009; Bondarouk, Horst, \& Engbers 2009) work. Technology Acceptance Model (TAM) model scales of perceived usefulness is appropriately measured using 5-items and Perceived Ease of Use actively involved in measuring a total of 3-items which was appropriately integrated by the work of Davis, (Davis, 1989). Post-Acceptance Model scales of User Satisfaction towards e-HRM was operationalized with a 3-items, and e-HRM Continuance Usage Intention was operationalized with a 4-items scale adapted from (Bhattacherjee 2001). Finally, SCA was measured using an 11-items scale developed by interviewing HRM experts within the context based on (Ruel, Bondarouk \& Velde, 2007).

\subsection{Data Analysis}

In this work SPSS AMOS software was used for data analyses. As a first step, descriptive and inferential statistics were reported through frequency analysis, as this type of analysis is useful for the classification of subject profiles based on specific socio-demographic data. This section describes the sample of the study showing the percentages of respondents according to their demographic variables (gender, age, education level, job description, experience, and e-HRM usage Distribution in years).

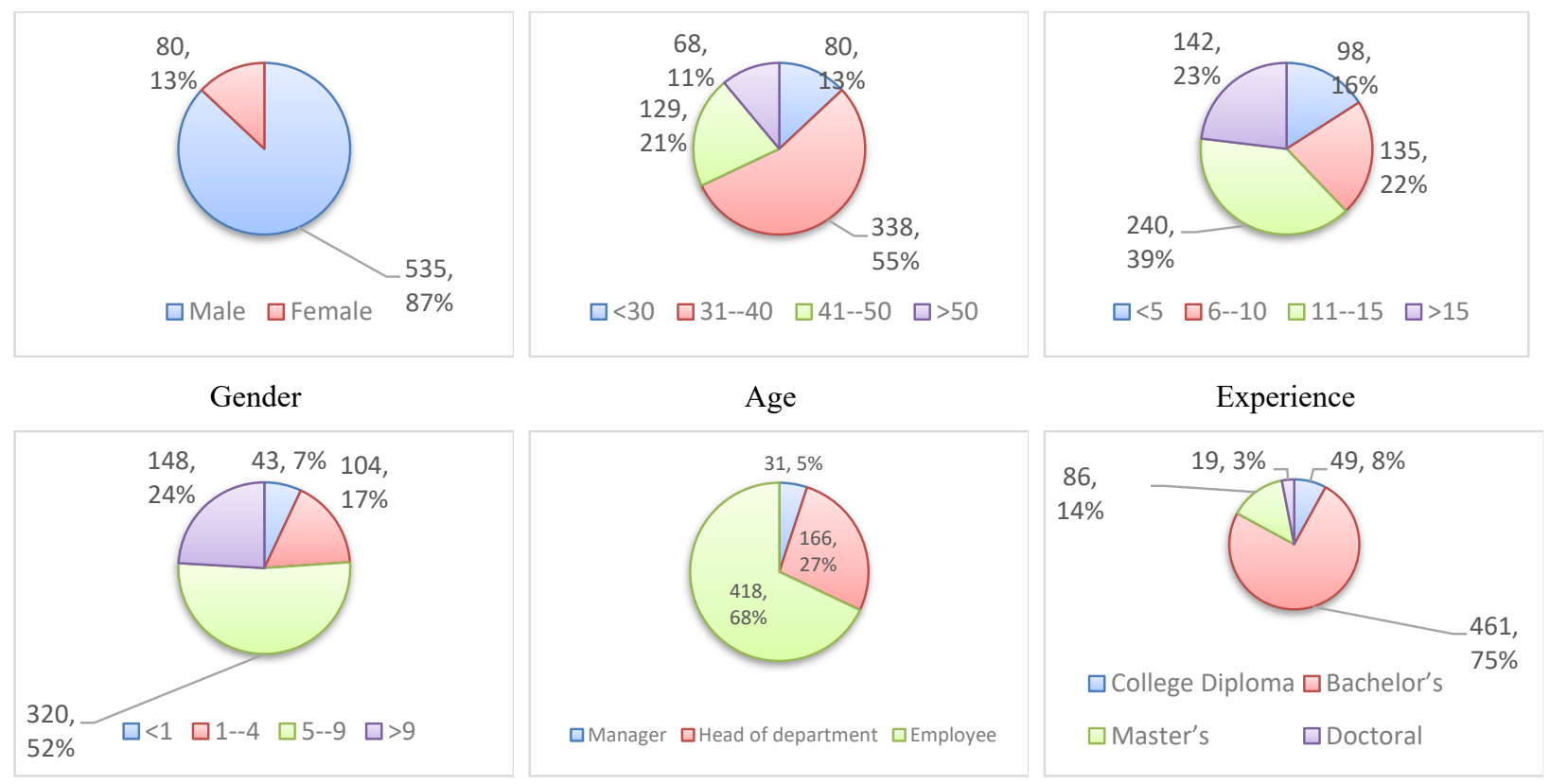

E-HRM usage in years

Job Description

Educational Level

Fig. 2. Descriptive and Inferential Statistics 
As shown in Fig. 2, the data revealed that the participants consisted of (87\%) male personnel and the rest were females. Regarding the age, the table shows that (55\%) of the respondents were between (31-40) years of age, $(21 \%)$ were of the age range from (41-50) years old; furthermore, (13\%) were below (30 years old) and the rest of sample ages were all above (50 years old). Thus, the largest percentage of the sample was the respondents from (31-40 years old), due to the young Jordanian society . Usually in this age range, respondents are more motivated and technologically oriented. Human capital "is a collection of knowledge, talents, skills, abilities, experience, and training possessed by an individual". It is important to note that education is a vital factor in the workplace. The data showed that (75\%) of the employees have bachelor's degree, $(14 \%)$ have master's degree, and (8\%) have college diplomas, and the rest have doctorate degrees. Overall, the sample seems to be well-educated. In terms of the job description, it illustrates that the sample comprises $(68 \%)$ employees, $(26.8 \%)$ are heads of department, and (5\%) are managers in HRM departments. The table indicates that (39.2\%) of respondents have been working for their organizations from (11 to 15 years). (23\%) of the respondents have (more than 16 years) of experience; and (22\%) of the respondents have experience of (6 to 10 years); and the rest of (less than 6 years). Thus, the largest percentage was the respondents with experience from (11-15) years who are well experienced and professional in their field. The dataset shows $(52.2 \%)$ of the surveyed organizations have been using e-HRM for about (5-9) years; and (24.4\%) have been using e-HRM for more than (9) years; and (17.2\%) have been using the system between (1 and 4) years and the rest less than a year, which proves the general direction towards e-HRM Adoption. Also, as shown in Table 2, the researchers compare the model fits, and the fit indices that produce a desirable result was the proposed model, the single factor model was worse. It presents two independent models; the proposed model produced a better fit. Results indicate as illustrated in table below, that the measurement model provides a good fit to the data $(\mathrm{TLI}=.79, \mathrm{GFI}=.80, \mathrm{CFI}=.78, \mathrm{IFI}=.78, \mathrm{RMR}=.050, \mathrm{RMSEA}=.075, \mathrm{X} 2=$ 3.91). The single factor model is where all the study variables were loaded into a single factor. A single factor model failed to fit the data satisfactorily (e.g., $\mathrm{TLI}=.28, \mathrm{GFI}=.48, \mathrm{CFI}=.32, \mathrm{IFI}=.33, \mathrm{RMR}=.119, \mathrm{RMSEA}=.142, \mathrm{X}^{2}=9.86$ ). $\mathrm{These}$ findings suggest that common source bias does not constitute a serious threat to the validity of the study.

Table 1

Goodness of Fit Statistics for Measurement Model

\begin{tabular}{ccc}
\hline Goodness-of-fit indices & Single Factor Model \\
\hline Chi-square $\left(\mathrm{X}^{2}\right)$ & $7494.5_{(760)}$ & .28 \\
TLI & .48 & .78 \\
GFI & .32 & .78 \\
CFI & .33 & .78 \\
IFI & .119 & .050 \\
RMR & .142 & .075 \\
PLSEA & .000 & .000 \\
$X^{2} / \mathrm{df}$ & 9.86 & 3.91 \\
\hline
\end{tabular}

Note: (1) ( $\chi^{2}$ ): Chi-square; (2) (TLI): The Tucker-Lewis Coefficient; (3) (GFI): The Goodness of Fit Index; (4) (CFI): Comparative Fit Index; (5) (IFI): Incremental Fit Index; (6) (RMR): Root Mean Square Residual; \& (7) (RMSEA): Root Mean Square Error of Approximation ** All values were significant (Anderson \& Gerbing, 1988)

According to Kline (1998), an observation of the discriminant validity is observable through analyzing the value of correlation between the study variables, he argued that if the value does not exceed (.85), then there is evidence of discriminant validity and vice versa. Next, Cronbach's alpha $(\alpha)$ used in assessing the scale reliability (Cronbach, 1951), as most researchers have done and are still doing. As stated above the validation approach is applicable in ascertaining the level of reliability, validity, and unidimensionality of the noted scales measurements. First, across measurement models, factor and item loadings were equal or above (.40), the accepted cut-off point (Bagozzi \& Yi, 1988; Ford, MacCallum, \& Tait, 1986). For the sake of data purification and screening, items e-R3,4, "E-C5,6; e-P15,16; PU25,26,27; CUI 33 measurement scale; The retained item loadings range from .40 to .84 , moreover, the high mean values and standard deviation, providing evidence of convergent and discriminant validity. According to the previous analysis, this procedure was conducted following recommendations from Bagozzi \& Yi (1988) and Hair et al. (1998). Overall, the constructs exhibited sound measurement properties. Next, the researchers observed the consistencies in the measurement model practices that utilize reliability levels. Alternatively, this means that the Cronbach's alpha coefficient is appropriately applicable in the process effectiveness. The reliability coefficients for the variables were all acceptable, although (Nunnally, 1978) set a benchmark of (.70). But recent scholars like Fornell and Larcker (1981), Hair et al. (1998) and Hair, Black, Babin, \& Anderson (2010) stated that (.60) is adequate when the sample size is higher than $n=200$. The current study has a huge sample size.

\subsection{Correlation and Regression Analysis}

To assess whether aggregating the score is statistically justifiable, this paper employed Intra-Class Correlation (ICC) analyses following procedures set forth by James (1982). This paper is also interested in looking into the linear dependency between the current study variables; as such Pearson correlation analysis was employed. As shown in Table 2, ICC with the aid of two-way mixed and absolute agreement definitions were used to assess the level of agreement between personnel. The aim was to check whether personnel in different firms can be differentiated on the variables under investigation. Single 
and average measures were reported for the variables. Overall, the F-value for ANOVA tests were all significant ( $\mathrm{p}<.001)$. The current outcome delineates that the responses were not associated with a particular branch or firm but rather the perception of the participants. These procedures have been used in various studies (Walumbwa, Avolio, Gardner, Wernsing, \& Peterson, 2008).

Table 2

Aggregation of the study variables

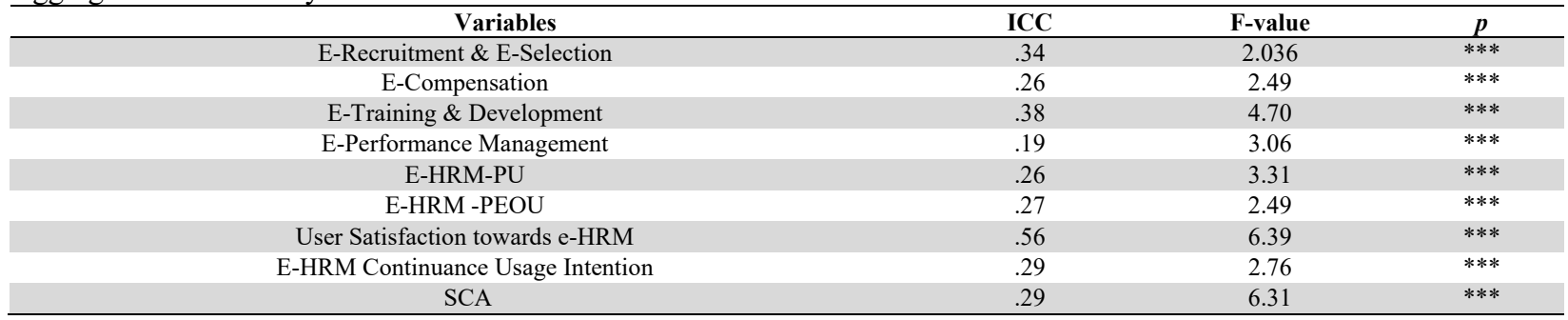

In Table 3, the researchers report alpha values, means, SD and the correlation coefficients showing the nature and direction of the association of the measurement variables. "E-Recruitment \& E-Selection positively correlates with e-HRM-PU, eHRM -PEOU and SCA respectively $(\mathrm{r}=.366, \mathrm{p}<.01)(\mathrm{r}=.382, \mathrm{p}<.01)(\mathrm{r}=.139, \mathrm{p}<.01)$." E-Compensation positively correlates with e-HRM-PU and PEOU respectively $(\mathrm{r}=.197, \mathrm{p}<.01)(\mathrm{r}=.219, \mathrm{p}<.01)$; but an insignificant relationship uncovers for SCA $(r=.050, \mathrm{p}>.10)$. E-Training and Development positively correlates with e-HRM-PU and PEOU respectively $(\mathrm{r}=.387, \mathrm{p}<.01)(\mathrm{r}=.347, \mathrm{p}<.01)$. But an insignificant relationship was uncovered for SCA $(\mathrm{r}=.076, \mathrm{p}>.10)$. EPerformance Management positively correlates with e-HRM-PU, PEOU and SCA respectively $(r=.152, p<.01)(r=.382$, $\mathrm{p}<.01)(\mathrm{r}=.144, \mathrm{p}<.01)$. E-HRM-PU, PEOU, User Satisfaction towards e-HRM and Continuance Usage Intention positively correlates with SCA respectively $(r=.171, p<.05)(r=.149, p<.01)(r=.329, p<.01)(r=.339, p<.01)$. Finally, none of the association was greater than $(.80)$, this provides additional support for convergent and discriminant validity of measures (Kline, 1998). In general, the significant relationships between the measurement variables provided primary support for the proposed hypotheses.

Table 3

Means, SD, \& correlations of study variables

\begin{tabular}{|c|c|c|c|c|c|c|c|c|c|}
\hline Variables & 1 & 2 & 3 & 4 & 5 & 6 & 7 & 8 & 9 \\
\hline E-Recruitment & - & & & & & & & & \\
\hline E-Compensation & $.173 * *$ & - & & & & & & & \\
\hline E- T \& D & $.330 * *$ & $.602 * *$ & - & & & & & & \\
\hline E-Performance & $.088^{*}$ & $.146^{* *}$ & $.154 * *$ & - & & & & & \\
\hline E-HRM-PU & $.366^{* *}$ & $.197 * *$ & $.387 * *$ & $.152 * *$ & - & & & & \\
\hline E-HRM -PEOU & $.382 * *$ & $.219 * *$ & $.347 * *$ & $.382 * *$ & $.643 * *$ & - & & & \\
\hline E-HRM- US & $205^{* *}$ & $.160 * *$ & $.290 * *$ & $291 * *$ & $.212 * *$ & $.284 * *$ & - & & \\
\hline E-HRM - CUI & $153^{* *}$ & $.174 * *$ & $.271 * *$ & $.212 * *$ & $.328 * *$ & $.290 * *$ & $.704 * *$ & - & \\
\hline SCA & $.139 * *$ & .050 & .076 & $.144 * *$ & $.171^{*}$ & $.149^{* *}$ & $.329 * *$ & $.339 * *$ & - \\
\hline Mean & 4.54 & 4.29 & 4.42 & 3.28 & 4.33 & 4.17 & 3.47 & 3.53 & 3.45 \\
\hline SD & .47 & .69 & .47 & .89 & .52 & .53 & .86 & .81 & .77 \\
\hline
\end{tabular}

Note: Composite scores for each variable were computed by averaging respective item scores.

Alpha and SD *Correlations are significant at the .05 level **Correlations are significant at the .01 level.

\subsection{Hypothesis Testing}

SEM was chosen due to the nature of the study model, a Mediated-Moderated Model. To adequately test the mediation effects, a bias-corrected bootstrapping method was chosen following recommendations from (Preacher \& Hayes 2004). As shown in Table (5) and (6), to test hypotheses (1-6), a SEM was applied. The tables show the main effects of the variables on one another, the direct and indirect effects. The interaction effects are presented in the subsequent table. The empirical results from the SEM suggests that e-HRM practices positively influence SCA $(\beta=.104, p=.032)$. This outcome conforms to study predictions as such $\mathbf{H 1}$ received empirical support. In congruence with the researcher's prediction, e-HRM practices positively influences e-HRM-PU $(\beta=.380, \mathrm{p}<.001)$, hence, $\mathbf{H} 2$ received empirical support. Further analysis shows that e-HRM practices positively influence e-HRM-PEOU $(\beta=.503, \mathrm{p}<.001)$, thereby granting support for H3. As a next step, the study tested the impact of the mediators on the dependent variable. The researchers augment the impact of e-HRM-PU on SCA, a significant and positive relationship was uncovered $(\beta=.119, \mathrm{p}=.006)$. This outcome conforms to the prediction; as such $\mathbf{H 4}$ received empirical support. Contrary to the prediction, the impact of e-HRM-PEOU on SCA was insignificant $(\beta=.020, p$ $>.10$ ), as such $\mathbf{H 5}$ was rejected. As shown in table (6) and figure (2), the paper proposed that e-HRM- PU and PEOU mediate the relationship between e-HRM practices and SCA. With the aid of bootstrapping analysis, utilizing a resample of $(\mathrm{n}=$ 5,000) following (Hayes, 2015). A bias-corrected bootstrap with $(95 \%)$ confidence interval indicated that e-HRM- PU and PEOU mediated the relationship. The indirect effects of e-HRM practices on SCA were significant $(.055)(\mathrm{p}=.012,95 \%$ 
confidence interval: 0.014-0.097). This outcome conforms to the expectation that a partial mediation exists in the model; hence, $\mathbf{H 6}$ received empirical support.

Table 4

Maximum likelihood estimates for the research model.

\begin{tabular}{lllll}
\hline \multicolumn{1}{c}{ Exogenous Variables } & Endogenous Variables & SE & t-value & \multicolumn{1}{c}{} \\
\hline E- HRM & E-HRM- PU & .047 & 10.189 \\
E- HRM & E-HRM -PEOU & .044 & 14.417 \\
E- HRM & SCA & .090 & 2.144 \\
E-HRM- PU & SCA & .062 & 2.775 & $.032 * *$ \\
E-HRM -PEOU & SCA & .067 & .444 \\
\hline
\end{tabular}

Notes: *Significant at the $\mathrm{p}<0.05$ level (two-tailed); **significant at the $\mathrm{p}<0.01$ level (two-tailed).

Table 5

Mediation affects sizes for the study model.

\begin{tabular}{lllll}
\hline Exogenous Variables & Endogenous Variables & Total Effects & Direct Effects & Indirect Effects \\
\hline E- HRM & E-HRM- PU & .380 & .380 & .000 \\
E- HRM & E-HRM -PEOU & .503 & .503 & .000 \\
E- HRM & SCA & .160 & .104 & $.055[.014-.097 ; \rho=.012]$ \\
E-HRM- PU & SCA & .119 & .119 & .000 \\
E-HRM -PEOU & SCA & .020 & .020 & .000 \\
\hline
\end{tabular}

Notes: *Significant at the $\mathrm{p}<0.05$ level (two-tailed); ** significant at the $\mathrm{p}<0.01$

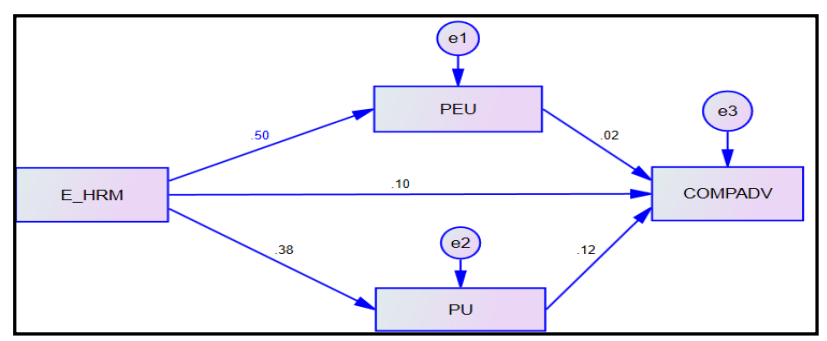

Fig. 3. Mediation Effects Analysis

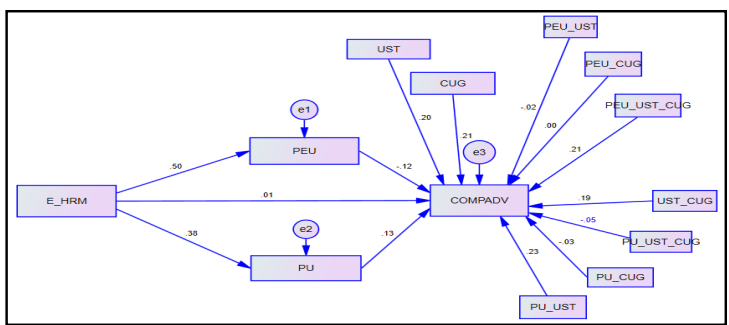

Fig. 3. Mediated-Moderated Analyses of the research model

\subsection{Mediated-Moderated Analysis}

Abiding by the rules set forth by renowned researchers (Aiken and West, 1996; Jacob, Cohen, West, and Aiken, 2013), the researchers assessed a three interaction effects between (1) e-HRM-PEOU, US and CUI; (2) e-HRM-PU, US and CUI. Aiken and West (1996) cautioned that predictor or exogenous and the moderator variables should be standardized to control for potential threats of collinearity among the researched variables. Therein, the researchers standardized e-HRM-PEOU, PU, US and CUI. Next, predictor variables were multiplied by the standardized moderator variables to produce the interaction terms. The researcher also included the 'main' effect during data analyses to prevent a biased estimate of the interactions. Tables 5 , 6, 7 and Fig. 3, Fig. 4 and Fig. 5 provide information concerning the proposed interaction effects.

\section{Table 6}

Three-way moderation effect of user satisfaction and e-HRM CUI

\begin{tabular}{|c|c|c|c|}
\hline Exogenous Variables & Endogenous Variables & $\boldsymbol{\beta}$ & $p$ \\
\hline E- HRM-PEOU & $\mathrm{SCA}$ & -.121 & $.003^{* *}$ \\
\hline E- HRM-PU & SCA & .130 & $* * *$ \\
\hline E- HRM -US & SCA & .204 & *** \\
\hline E-HRM- CUI & SCA & .210 & $* * *$ \\
\hline \multicolumn{4}{|l|}{ Interaction terms } \\
\hline E- HRM-PEOU $\times$ CUI & & .000 & .994 \\
\hline E-HRM US $\times$ E-HRM CUI & & .193 & $.007^{* *}$ \\
\hline E-HRM-PEOU $\times$ US*CUI & & .208 & *** \\
\hline \multicolumn{4}{|l|}{ Interaction terms } \\
\hline E-HRM-PU CUI & & -.034 & .326 \\
\hline E- HRM US * E- HRM CUI & & .193 & $.007^{* *}$ \\
\hline E- HRM-PU $*$ US*CUI & & -.052 & .134 \\
\hline
\end{tabular}

Notes: Significant at the $\mathrm{p}<0.05$ level (two-tailed); ${ }^{* * *}$ significant at the $\mathrm{p}<0.01$ level (two-tailed)

This paper hypothesized that user satisfaction and use e-HRM continuance usage intention moderates the relationship between e-HRM-PEOU and SCA. The findings in Table 6 show that the variables do not moderate the relationship. The researchers further conducted a slope analysis evident in Fig. 3. Yet no moderation was uncovered, as such $\mathbf{H} 7$ was rejected. 
Table 7

Slope difference analyses for hypothesis 7

\begin{tabular}{llc}
\hline Pair of slopes & t-value & p-value \\
\hline (1) and (2) & 1.020 & 0.309 \\
$(1)$ and (3) & 1.188 & 0.236 \\
$(1)$ and (4) & -0.150 & 0.881 \\
$(2)$ and (3) & -0.122 & 0.903 \\
$(2)$ and (4) & -1.478 & 0.141 \\
$(3)$ and (4) & -1.405 & 0.161 \\
\hline
\end{tabular}

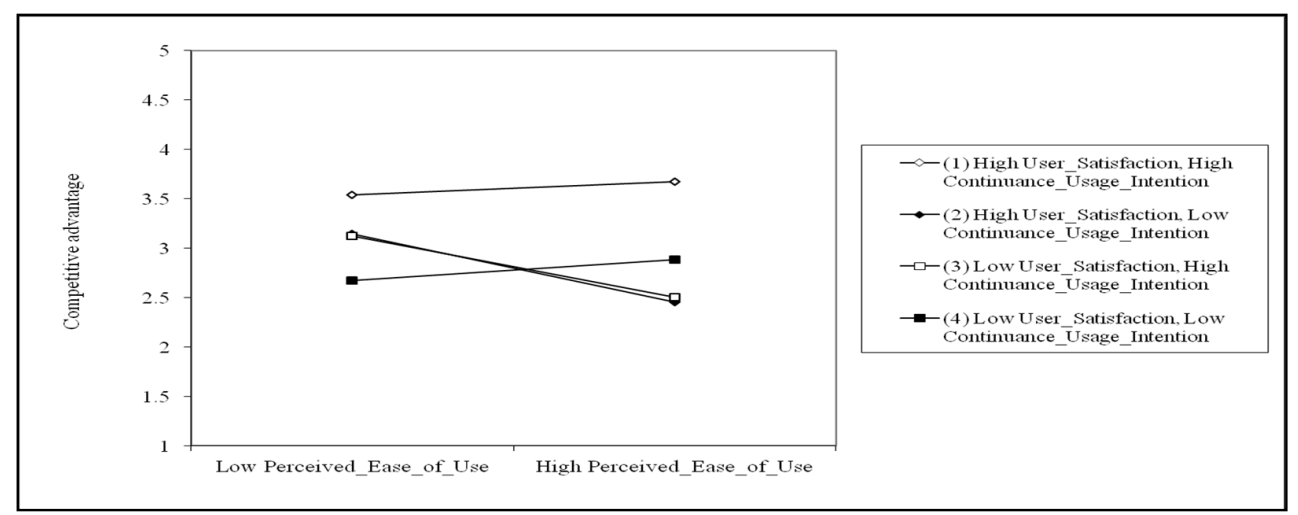

Fig. 5. Interaction effects of user satisfaction \& e-HRM continuance usage intention between e-HRM-PEOU \& SCA (Sources: Gaskin, 2016)

Finally, it was hypothesized that user satisfactions and use of e-HRM continuance usage intention moderate the relationship between e-HRM-PU and SCA. The findings in table (8) show that the aforementioned variables do not moderate the relationship. The researchers further conducted a slope analysis evident in Table 8 and Fig. 6 . Yet no moderation was uncovered, and as such, $\mathbf{H 8}$ was rejected.

\section{Table 8}

Slope difference analyses hypothesis 8

\begin{tabular}{lcc}
\hline Pair of slopes & t-value & p-value \\
\hline (1) and (2) & -0.422 & 0.675 \\
$(1)$ and (3) & 1.132 & 0.259 \\
$(1)$ and (4) & 1.565 & 0.119 \\
$(2)$ and (3) & 1.708 & 0.089 \\
$(2)$ and (4) & 1.849 & 0.065 \\
$(3)$ and (4) & & 0.903 \\
\hline
\end{tabular}

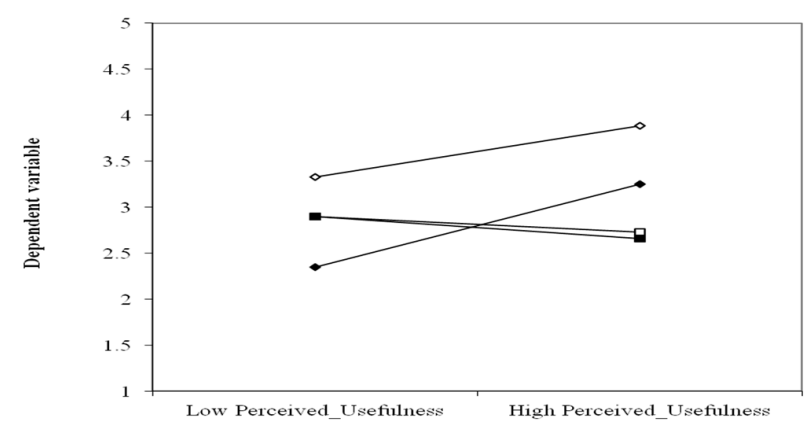

$-($ (1) High User_Satisfaction. Higl Continuance_Usage_Intention (2) High User_Satisfaction, Low

$\longrightarrow$ (3) Low User_Satisfaction, High Continuance_Usage_Intention (4) Low User_Satisfaction, Low
Continuance_Usage Intention

Low Perceived_Usefulness High Perceived_Usefulness

Fig. 6. Interaction effects of user satisfaction \& e-HRM continuance usage intention between e-HRM-PU \& SCA (Sources: Gaskin, 2016). 


\section{Discussion and Conclusions}

The results of the SEM analyses indicate that the proposed measurement model and structural model satisfy the necessary fit conditions. This study asserted that e-HRM practices have a significant influence on SCA. The outcome conforms to prediction, as e-HRM practices influence SCA. This link has not been tested by prior scholars, although a number of researchers noted that e-HRM contributes to the effectiveness of HRM practices (Ruel et al., 2007), this notion also received empirical support from Ruel and Kaap (2012), who added that e-HRM can enhance HRM value creation. Value creation has to do with the creation of efficiency and HR service quality in an organization, as e-HRM may help HR to increase its value (Wahyudi \& Park, 2014). Existing work on e-HRM majorly relied on the TAM model (Huang et al., 2004). This work predicted that e-HRM practices influence e-HRM-PU. The outcome conforms to prior findings of Marler and Fisher (2010), which illustrated that PU of e-HRM is an important contextual variable for e-HRM; and corroborated by Wickramasinghe (2010), who asserted that PU is associated with e-HRM systems signals some form of compatibility. This study has laid out the fact that e-HRM practices can enhance e-HRM-PU from HR perspective. A study found that e-HRM has a connection with facilitating conditions, PEOU (Ruel \& Kaap, 2012). The study hypothesized that e-HRM practices influence e-HRM- PEOU. As expected, e-HRM practices influence e-HRM- PEOU, in line with Voermans and Veldhoven's (2007) study, which identified PEOU as a determinant of intention of using e-HRM practices. The study supported the hypothesis, and the above findings hence contribute to an understanding of how e-HRM practices interact with e-HRM -PEOU from HR perspective. Technically, due to recent global fierce competition, and organizational reengineering, this work attempts to observe how e-HRMPU and SCA interact from HR perspectives. The impact of e-HRM-PU on CA was significant and positive. This outcome conforms to the researcher's prediction. Panayotopoulou, et al. (2007), and Bondarouk et al. (2017) provided earlier evidence by showing that e-HRM promised to lead to efficiency gains, and most researchers in the past decade advocated e-HRM's strong contribution to the bottom line. The current study corroborates the findings with employees in an Arabian work setting. It is important to note that results are comparable on this point. Interestingly, e-HRM-PEOU did not have a significant impact on SCA. This finding contradicts those of Huselid et al. (1997, p. 172) who noted that "technical and strategic effectiveness of HRM" are activities governed in "socially constructed environments". Henceforth, meeting the expectations of stakeholders may equate to acceptance and organizational growth. This means that e-HRM-PEOU may increase organizational SCA. Unfortunately, this assertion has been nullified by the study, and the pattern of the result has been verified in a study conducted by Ruel, et al. (2007), who found that e-HRM-PEOU did not enhance strategic and technical HRM effectiveness. Kossek et al. (1994) noted that top managers showed high resistance as they did not perceive e-HRM systems having use for their own careers. Contrary to the above argument, recent findings like those of Hussain et al. (2007), verified positive attitudes of HR professionals who perceived e-HRM as a crucial and enabling technology. According to Bondarouk and Brewster (2016), it is the user's perceptions of e-HRM applications that determine, to a great extent, how and whether eHRM will be used. It is critical to note that e-HRM is a part of that wider picture requiring crucial analysis from PU and PEOU. This study proposed that e-HRM-PU and e-HRM-PEOU mediate the relationship between e-HRM practices and SCA. This outcome conforms to the researcher's expectation as uncovering a partial mediation in the model. E-HRM practices reduce time and effort needed for administrative tasks, increase accuracy of data and speed and ease of information sharing, and technically simplify all HRM processes (Parry, \& Tyson, 2011). In doing so, e-HRM practices harmonize HR activities (Martin \& Reddington, 2010), asserting that better e-HRM- PU and e-HRM-PEOUs are key determinants for the facilitation of focus strategy, value-adding tasks and plans (Panos, \& Bellou, 2016). Hence, JIS can easily gain SCA as a result of eHRM practices well represented between e-HRM- PU and e-HRM-PEOU.

The researchers gauged for a potential three-way interaction of user satisfaction with e-HRM and e-HRM continuance usage intention which is adopted by PAM as a moderator variable on (1) the relationship between "e-HRM-PEOU and SCA", and (2) the relationship between "e-HRM-PU and SCA". The outcome shows that the aforementioned variables did not jointly moderate the relationships. This is surprising; as Martin and Reddington (2010) noted that user acceptance of IT applications can act as a moderator in the relationship between HR strategy and e-HRM outcomes. In addition, Bjorkman and Lervik (2007) added that satisfaction levels with existing HR systems in the subsidiaries are likely to have an influence on the adoption levels of new HR practices. E-HRM was reported as beneficial to employee satisfaction (Panayotopoulou et al., 2007) and satisfaction related to HR processes (Cronin, et al. 2006).

\section{Academic and Managerial Implications}

The paper adds to the evidence that e-HRM practices can help organizations achieve SCA that arises from HR department performance, e-HRM practices have more influence on e-HRM-PEOU than e-HRM-PU; surprisingly e-HRM-PU turnout has a stronger effect on SCA. Moreover, the study indicates that the e-HRM-PEOU is less likely to be a critical factor SCA than how it was proposed in the TAM by Davis (1989). This finding is in line with other TAM studies, which found that PEOU has less of an impact on technology acceptance than PU (Yousafzai, et al.2012). This means that users tend to rely on their PU when using a new technology including e-HRM.

According to managerial implications, the researchers found out that e-HRM practices can enhance SCA. In agreement with prior findings (e.g., Steijn \& van den Muyzenberg, 2012; Wahyudi \& Park 2014), the current outcome delineates that such practices can help firms become more strategic; it is important to note that, this strategy cannot be achieved by over relying on e-HRM practices, but rather with the support of existing organizational internal and external resources. This paper utilized both the individual and organizational level as units of analysis, plus the context is a non-western context. Interestingly enough, the studies lack a precise and in-depth analysis of the causes of SCA through HR perspective. 


\section{Future Research}

This study has tested the impact of e-HRM on attaining SCA and did not take into consideration other factors that can also influence attaining sustainable SCA such as: the organizational culture, the changed management style of the organization and the need to have to clarify the strategic purposes and goals of using such systems through comprehensive and continuous trainings and workshops for the employees using this system. JIS must maintain the actual level of orientation towards implementation of e-HRM and clarify the purposes of its implementation as a helping tool and not a replacement for these employees, it should keep a consistent rate of growth and development for the IT infrastructure, because of its big importance as an investment for JIS and its positive effect on the successful implementation of e-HRM in the context of JIS.

There may be other contextual factors hurdling the relationship, so future studies could ascertain this link in other work settings and/or cultural settings, in addition to that the researcher's recommendation to future scholars is to use a longitudinal design, as this type of design allow researchers to directly observe intra-individual changes over time and address some of the limitations in the current study. Regardless, however, potential researchers must aim to vary their source methodology and collect data from various points in time. Future study should replicate the research findings in non-western settings to validate the current outcome, so the researcher therefore recommends scholars in other Arab countries to conduct similar research, to verify the results of this study and establish the current model. Furthermore, this paper was curious about the role of moderating factors that may enhance SCA (i.e., user satisfaction with e-HRM and use e-HRM continuance usage intention), which produce insignificant associations and effects in the measurement model. However, future research can examine the interaction factors as a comparative frame of research and to be applied in other sectors.

\section{Research Limitations}

The current paper includes operational and informative outcomes but inherits a number of limitations that should be considered by readers and future scholars. First, the potential confounding of user satisfaction with e-HRM and use e-HRM continuance usage intention, it is ill to rule out that the potential effects of self-efficacy and training to use e-HRM system, also other contextual factors such as personal education, work experience and other life events like generation may have confounding effects on the data. Moreover, it was not possible to have formal in-depth interviews due to time, logistics and procedural operations. The findings in this study cannot be generalized, as the study data was garnered from Jordan, hence the outcome is only associated with the country and the sector. More specifically, the applicability of the current outcome to other countries and sectors is somewhat questionable without empirical proof through research.

\section{References}

Aiken, L. S., West, S. G., \& Reno, R. R. (1991). Multiple regression: Testing and interpreting interactions. sage.

Alajmi, S. A., \& Alenezi, M. A. (2016). Human resource management practice and competitive advantage: the mediator role of person organization fit. Global Journal Of Human Resource Management, 4(1), 65-82.

Alaali, N., Al Marzouqi, A., Dahabreh, F., Mouzaek, E., Portal, R., \& Salloum, S. (2021) The impact of adopting corporate governance strategic performance in the tourism sector: A case study in the Kingdom of Bahrain. Journal of Legal, Ethical and Regulatory, 24(1), 1-18.

Alameeri, K., Alshurideh, M., Al Kurdi, B., \& Salloum, S. A. (2020, October). The effect of work environment happiness on employee leadership. In International Conference on Advanced Intelligent Systems and Informatics (pp. 668-680). Springer, Cham.

Alkalha, Z., Al-Zu'bi, Z., Al-Dmour, H., Alshurideh, M., \& Masa'deh, R. (2012). Investigating the effects of human resource policies on organizational performance: An empirical study on commercial banks operating in Jordan. European Journal of Economics, Finance and Administrative Sciences, 51(1), 44-64.

Al Kurdi, B., \& Alshurideh, M. \& Al afaishata, T. (2020). Employee retention and organizational performance: Evidence from banking industry. Management Science Letters, 10(16), 3981-3990.

Al Kurdi, B., Elrehail, H., Alzoubi, H., Alshurideh, M., \& Al-Adaila, R. (2021). The interplay among HRM practices, job satisfaction and intention to leave: An empirical investigation. Journal of Legal, Ethical and Regulatory, 24 (1), 1-14.

Al-Maghrabi, T., Dennis, C., \& Halliday, S. V. (2011). Antecedents of continuance intentions towards e-shopping: the case of Saudi Arabia. Journal of Enterprise Information Management, 24(1), 85-111.

Al Shebli, K., Said, R. A., Taleb, N., Ghazal, T. M., Alshurideh, M. T., \& Alzoubi, H. M. (2021, June). RTA’s Employees' Perceptions Toward the Efficiency of Artificial Intelligence and Big Data Utilization in Providing Smart Services to the Residents of Dubai. In The International Conference on Artificial Intelligence and Computer Vision (pp. 573-585). Springer, Cham.

Alshraideh, A. T. R., Al-Lozi, M., \& Alshurideh, M. T. (2017). The impact of training strategy on organizational loyalty via the mediating variables of organizational satisfaction and organizational performance: An empirical study on Jordanian agricultural credit corporation staff. Journal of Social Sciences (COES\&RJ-JSS), 6(2), 383-394.

Alsuwaidi, M., Alshurideh, M., Al Kurdi, B., \& Salloum, S. A. (2020, October). Performance appraisal on employees' motivation: a comprehensive analysis. In International Conference on Advanced Intelligent Systems and Informatics (pp. 681 693). Springer, Cham.

Ammari, G., Alkurdi, B., Alshurideh, A., \& Alrowwad, A. (2017). Investigating the impact of communication satisfaction on organizational commitment: a practical approach to increase employees' loyalty. International Journal of Marketing Studies, 9(2), 113-133. 
Anderson, J. C., \& Gerbing, D. W. (1988). Structural equation modeling in practice: A review and recommended two-step approach. Psychological bulletin, 103(3), 411-423.

Anjum, M. J. (2011). Users satisfaction and ERP implementation success. Information Management and Business Review, 3(5), 265-272.

Bagozzi, R. P., \& Yi, Y. (1988). On the evaluation of structural equation models. Journal of the Academy of Marketing Science, 16(1), 74-94.

Bell, B. S., Lee, S. W., \& Yeung, S. K. (2006). The impact of e-HR on professional competence in HRM: Implications for the development of HR professionals. Human Resource Management: Published in Cooperation with the School of Business Administration, The University of Michigan and in alliance with the Society of Human Resources Management, 45(3), 295-308.

Bhattacherjee, A. (2001). Understanding information systems continuance: An expectation-confirmation model. MIS quarterly, 25(3), 351-370.

Björkman, I., \& Lervik, J. E. (2007). Transferring HR practices within multinational corporations. Human Resource Management Journal, 17(4), 320-335.

Bokhari, R. H. (2005). The relationship between system usage and user satisfaction: a meta-analysis. Journal of Enterprise Information Management. 18(2), 211-234.

Bondarouk, T., \& Brewster, C. (2016). Conceptualising the future of HRM and technology research. The International Journal of Human Resource Management, 27(21), 2652-2671.

Bondarouk, T. V., \& Ruël, H. J. (2009). Electronic Human Resource Management: challenges in the digital era. The International Journal of Human Resource Management, 20(3), 505-514.

Bondarouk, T., Parry, E., \& Furtmueller, E. (2017). Electronic HRM: four decades of research on adoption and consequences. The International Journal of Human Resource Management, 28(1), 98-131.

Bondarouk, T., ter Horst, V., \& Engbers, S. (2011). Exploring perceptions about the use of e-HRM tools in medium sized organizations. In Enterprise Information Systems: Concepts, Methodologies, Tools and Applications (pp. 1379-1398). IGI Global.

Cavana, R., Delahaye, B., \& Sekeran, U. (2001). Applied business research: Qualitative and quantitative methods. John Wiley \& Sons.

Cronin, B., Morath, R., Curtin, P., \& Heil, M. (2006). Public sector use of technology in managing human resources. Human Resource Management Review, 16(3), 416-430.

Davis, F. D. (1989). Perceived usefulness, perceived ease of use, and user acceptance of information technology. MIS Quarterly, 13(3), 319-340.

Deshwal, P. (2015). Role of e-HRM in organizational effectiveness and sustainability. International Journal of Applied Research, 1(12), 605-609.

Afacan Findıklı, M., \& Bayarçelik, E. B. (2015). Exploring the outcomes of Electronic Human Resource Management (EHRM)?. In 11th International Strategic Management Conference.

Ford, J. K., MacCallum, R. C., \& Tait, M. (1986). The application of exploratory factor analysis in applied psychology: A critical review and analysis. Personnel psychology, 39(2), 291-314.

Fornell, C., \& Larcker, D. F. (1981). Evaluating structural equation models with unobservable variables and measurement error. Journal of Marketing Research, 18(1), 39-50.

Gaskin, J. (2016). Name of section. Gaskination's statWiki.

Ghazzawi, K., Al-Khoury, P., \& Saman, J. (2014). The effect of implementing technology in HRM on the level of employee motivation. 4(2), 33-39.

Haines, V. Y., \& Lafleur, G. (2008). Information technology usage and human resource roles and effectiveness. Human Resource Management: Published in Cooperation with the School of Business Administration, The University of Michigan and in alliance with the Society of Human Resources Management, 47(3), 525-540.

Hair, J. F., Anderson, R. E., Babin, B. J., \& Black, W. C. (2010). Multivariate data analysis: A global perspective (Vol. 7).

Hair, J. F., Anderson, R. E., Tatham, R. L., \& Black, W. C. (1998). Multivariate Data Analysis New Jersey. Prentice-Hall.

Hayes, A. F. (2015). An index and test of linear moderated mediation. Multivariate Behavioral Research, 50(1), 1-22.

Hendrickson, A. R. (2003). Human resource information systems: Backbone technology of contemporary human resources. Journal of Labor Research, 24(3), 381-394.

Ho, C. H. (2010). Continuance intention of e-learning platform: Toward an integrated model. International Journal of Electronic Business Management, 8(3), 206-215.

Huang, J. H., Yang, C., Jin, B. H., \& Chiu, H. (2004). Measuring satisfaction with business-to-employee systems. Computers in Human Behavior, 20(1), 17-35.

Husleid, M. (1995). The Impact of HRM Practices on Turnover, Productivity, \& Corporate Financial Performance. Information \& Management, 32, 113-121.

Hussain, Z., Wallace, J., \& Cornelius, N. E. (2007). The use and impact of human resource information systems on human resource management professionals. Information \& Management, 44(1), 74-89.

Ibrahim, H., \& Yusoff, Y. M. (2013). Satisfaction Towards E-HRM in government organizations of Malaysia: A proposed model based on field theory. In International Conference on Social Science Research, ICSSR, (4-5). 
Iyiola, O. O., \& Osibanjo, A. O. (2014). e-Human Resource Management and Organizational Performance (e-HRM) in the Nigerian Banking Industry: An Empirical Study of Guaranty Trust Bank Plc. ANVESHA The Journal of Management, Indian Education Society, Management College and Research Centre, 7(1), 10-20.

Cohen, P., West, S. G., \& Aiken, L. S. (2014). Applied multiple regression/correlation analysis for the behavioral sciences. Psychology press.

James, L. R. (1982). Aggregation bias in estimates of perceptual agreement. Journal of Applied Psychology, 67(2), 1-20.

Jaradat, S. A., \& Azaam, A. A. (2013). Impact of human resources management practices on achieving competitive advantage for industrial companies (an empirical study at Al Hassan Industrial Estate-Jordan). In Information and Knowledge Management, 3(12), 29-39.

Karampour, A., Nazari, Y., Alinia, S., \& Kameli, A. (2014). Survey and comparison of e-HRM systems in oil and gas companies Lorestan province. International Journal of Management and Humanity Sciences, 3(1), 1308-1315.

Khashman, A. M., \& Al-Ryalat, H. A. (2015). The impact of electronic human resource management (E-HRM) practices on business performance in Jordanian telecommunications sector: The employees perspective. Journal of Management Research, 7(3), 115-129.

Kline, R. B. (2015). Principles and practice of structural equation modeling. Guilford publications.

Kossek, E. E., Young, W., Gash, D. C., \& Nichol, V. (1994). Waiting for innovation in the human resources department: Godot implements a human resource information system. Human Resource Management, 33(1), 135-159.

Kurdi, B., Alshurideh, M., \& Alnaser, A. (2020). The impact of employee satisfaction on customer satisfaction: Theoretical and empirical underpinning. Management Science Letters, 10(15), 3561-3570.

Laumer, S., Eckhardt, A., \& Weitzel, T. (2010). Electronic human resources management in an e-business environment. Journal of Electronic Commerce Research, 11(4), 240-250.

Lee, S. M., Kim, I., Rhee, S., \& Trimi, S. (2006). The role of exogenous factors in technology acceptance: The case of objectoriented technology. Information \& Management, 43(4), 469-480.

Lengnick-Hall, M. L., \& Moritz, S. (2003). The impact of e-HR on the human resource management function. Journal of labor Research, 24(3), 365-379.

Liao, C., Chen, J. L., \& Yen, D. C. (2007). Theory of planning behavior (TPB) and customer satisfaction in the continued use of e-service: An integrated model. Computers in Human Behavior, 23(6), 2804-2822.

Liao, C., Palvia, P., \& Chen, J. L. (2009). Information technology adoption behavior life cycle: Toward a Technology Continuance Theory (TCT). International Journal of Information Management, 29(4), 309-320.

Mahmood, M. A., Burn, J. M., Gemoets, L. A., \& Jacquez, C. (2000). Variables affecting information technology end-user satisfaction: a meta-analysis of the empirical literature. International Journal of Human-Computer Studies, 52(4), 751771.

Elayan, M. B. (2020). Examining the Impact of HRIS on Attaining Competitive Advantage in Higher Education Market: A Literature Review. International Journal of Innovation, Creativity and Change, 12(9), 436-455.

Marler, J., \& Fisher, S. (2010). An Evidence-based Review of E-HRM \& Strategic Human Resource Management. European Academic Workshop on Electronic Human Resource Management Proceedings, 23, 18-36.

Martin, G., \& Reddington, M. (2010). Theorizing the links between e-HR and strategic HRM: a model, case illustration and reflections. The International Journal of Human Resource Management, 21(10), 1553-1574.

Masum, A. K. M., Kabir, M. J., \& Chowdhury, M. M. (2015). Determinants that influencing the adoption of E-HRM: An empirical study on Bangladesh. Asian Social Science, 11(21), 117.

McGill, T., \& Klobas, J. (2008). User developed application success: sources and effects of involvement. Behaviour \& Information Technology, 27(5), 407-422.

Naidoo, R., \& Leonard, A. (2007). Perceived usefulness, service quality and loyalty incentives: Effects on electronic service continuance. South African Journal of Business Management, 38(3), 39-48.

Nunnally, J. C. (1978). Psychometric Theory. $2^{\text {nd }}$ ed.

Oswal, N., \& Narayanappa, G. L. (2014). Evolution of HRM to E-HRM towards Organizational Effectiveness and Sustainability. International Journal of Recent Development in Engineering and Technology, 2(4), 7-14.

Panayotopoulou, L., Vakola, M., \& Galanaki, E. (2007). E-HR adoption and the role of HRM: Evidence from Greece. Personnel Review, 36(2), 277-294.

Panos, S., \& Bellou, V. (2016). Maximizing e-HRM outcomes: a moderated mediation path. Management Decision, 54(5), 1088-1109.

Parry, E., \& Tyson, S. (2011). Desired goals and actual outcomes of e-HRM. Human Resource Management Journal, 21(3), 335-354.

Preacher, K. J., \& Hayes, A. F. (2004). SPSS and SAS procedures for estimating indirect effects in simple mediation models. Behavior Research Methods, Instruments, \& Computers, 36(4), 717-731.

Ramezan, M. (2009). Measuring the effectiveness of human resource information systems in national iranian oil company an empirical assessment. Iranian Journal of Management Studies, 2(2), 129-1145.

Rangarao, J. P., \& Raju, S. R. D. (2014). e-HRM add value to the Human Resource Management to obtain optimum potentials from the available Human Resources. Indian Journal of Commerce and management (IJOCAM), 1(1), 1-9.

Rawash, H. N. (2012). The impact of electronic human resource management on organization's market share: An empirical study on the housing bank for trade and finance in Jordan. International Journal of Business and Social Science, 3(24), 113-120. 
Ruël, H., \& Van der Kaap, H. (2012). E-HRM usage and value creation. Does a facilitating context matter?. German Journal of Human Resource Management, 26(3), 260-281.

Ruël, H., Bondarouk, T., \& Looise, J. K. (2004). E-HRM: Innovation or irritation. An explorative empirical study in five large companies on web-based HRM. Management Revue, 15(3), 364-380.

Ruel, H. J., Bondarouk, T. V., \& Van der Velde, M. (2007). The contribution of e-HRM to HRM effectiveness: Results from a quantitative study in a Dutch Ministry. Employee relations.

Sanayei, A., \& Mirzaei, A. B. A. S. (2012). Designing a model for evaluating the effectiveness of E-HRM (case study: Iranian organizations). International Journal of Information Science and Management (IJISM), 6(2), 79-98.

Saunders, M., Lewis, P., \& Thornhill, A. (2009). Research methods for business students. Pearson education.

Schaupp, L. C. (2010). Web site success: Antecedents of web site satisfaction and re-use. Journal of Internet Commerce, 9(1), 42-64.

Seddon, K. R. (1997). Ionic liquids for clean technology. Journal of Chemical Technology \& Biotechnology: International Research in Process, Environmental AND Clean Technology, 68(4), 351-356.

Steijn, B. \& Van Den Muyzenberg, M. (2012). Human Resource Management in the Information Age”. In I. Snellen, M. Thaens, \& W. Donk (Eds.), Public Administration in the Information age: Revisited (252-263). Amsterdam, the Netherlands: IOS Press.

Stone, D. L., Stone-Romero, E. F., \& Lukaszewski, K. (2006). Factors affecting the acceptance and effectiveness of electronic human resource systems. Human Resource Management Review, 16(2), 229-244.

Strohmeier, S. (2007). Research in e-HRM: Review and implications. Human Resource Management Review, $17(1), 19-37$.

Thiruselvi, S., Yusliza, M. Y., Ramayah, T., \& Nur Zahitah, O. (2013). Continuance intention usage towards e-HRM. Proceedings Book of ICEFMO, Handbook on the Economic, Finance and Management Outlooks, 674-687.

Voermans, M., \& van Veldhoven, M. J. P. M. (2007). Attitude towards E-HRM: an empirical study at Philips. Personnel review. 36(6), 887-902.

Wahyudi, E., \& Park, S. M. (2014). Unveiling the value creation process of electronic human resource management: An Indonesian case. Public Personnel Management, 43(1), 83-117.

Walumbwa, F. O., Avolio, B. J., Gardner, W. L., Wernsing, T. S., \& Peterson, S. J. (2008). Authentic leadership: Development and validation of a theory-based measure. Journal of Management, 34(1), 89-126.

Wickramasinghe, V. (2010). Employee perceptions towards web-based human resource management systems in Sri Lanka. The International Journal of Human Resource Management, 21(10), 1617-1630.

Wixom, B. H., \& Todd, P. A. (2005). A theoretical integration of user satisfaction and technology acceptance. Information Systems Research, 16(1), 85-102.

Yarbrough, A. K., \& Smith, T. B. (2007). Technology acceptance among physicians: a new take on TAM. Medical Care Research and Review, 64(6), 650-672.

Yen, Y. R., \& Tsai, B. Y. (2011). Exploring the Influential Factors Toward the Continuance Intention of On-line Books Purchase. International Journal of Organizational Innovation, 3(4), 140-157.

Yousafzai, S. Y., Foxall, G. R., \& Pallister, J. G. (2007). Technology acceptance: a meta-analysis of the TAM: Part 2. Journal of Modelling in Management, 2(3), 281-304.

Yusoff, Y. M., Ramayah, T., \& Othman, N. Z. (2015). Why examining adoption factors, HR role and attitude towards using E-HRM is the start-off in determining the successfulness of green HRM. Journal of Advanced Management Science, 3(4), 337-343.

Zeithaml, V. A., Berry, L. L., \& Parasuraman, A. (1996). The behavioral consequences of service quality. Journal of marketing, 60(2), 31-46.

Zikmund, W. G. (2003). Business research methods. Language, $7^{\text {th }}$ Edition.

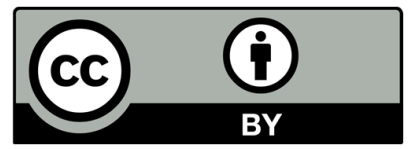

(C) 2022 by the authors; licensee Growing Science, Canada. This is an open access article distributed under the terms and conditions of the Creative Commons Attribution (CC-BY) license (http://creativecommons.org/licenses/by/4.0/). 